\title{
Chromatographic profile and bioactive
} compounds found in the composition of pupunha oil (Bactris gasipaes Kunth): implications for human health

\section{Perfil cromatográfico e compostos bioativos}

presentes na composição do óleo de pupunha

\section{(Bactris gasipaes Kunth): implicações}

\section{para a saúde humana}

\author{
Orquídea Vasconcelos dos SANTOS 1 (iD) 0000-0001-5423-1945 \\ Stephanie Dias SOARES ${ }^{1}$ (D) 0000-0002-4229-7805 \\ Pamela Cristina Sodré DIAS 1 (D) 0000-0002-2807-711x \\ Samanta de Paula de Almeida DUARTE ${ }^{1}$ (D) 0000-0002-5235-6880 \\ Mayara Priscila Lima dos SANTOS ${ }^{1}$ (D) 0000-0001-6673-4419 \\ Francisco das Chagas Alves do NASCIMENTO' ${ }^{1}$ (D) 0000-0002-2817-3312
}

\section{A B S T R A C T}

\section{Objective}

The presence of dietary bioactive compounds in the human diet becomes a major factor in combating the etiology of different pathologies. Thus, the aim of this investigation was to evaluate the fatty acids profile, cardiovascular functionality indices, bioactive compounds and spectroscopic pattern of peach palm oil (pupunha oil) and their impact on human health.

\section{Methods}

The oil was obtained by soxhlet extraction; the oil yield and qualities were determined according to the standards of the Association of Official Analytical Chemists. For the fatty acids profile, the practical recommendations of the

\footnotetext{
1 Universidade Federal do Pará, Centro de Ciências da Saúde, Faculdade de Nutrição. Campus do Guamá, R. Augusto Corrêa, n. 1, Cidade Universitária Prof. José da Silveira Netto, 66075-110, Belém, PA, Brasil. Correspondence to: OV SANTOS. E-mail: <orquideavs@ufpa.br>.

How to cite this article

Santos OV, Soares SD, Dias PCS, Duarte SPA, Santos MPL, Nascimento FCA. Chromatographic profile and bioactive compounds found in the composition of pupunha oil (Bactris gasipaes Kunth): implications for human health. Rev Nutr. 2020;33:e190146. http://dx.doi.org/10.1590/1678-9805202033e190146
} 
American Oil Chemists' Society and of the International Organization for Standardization were followed. Total carotenoids and polyphenols were determined by spectrophotometry; the composition of the chemical groups was determined by infrared spectroscopy. The anti-atherogenic, antithrombogenic and hypocholesterolemic indices were obtained using mathematical models.

\section{Results}

The results showed good quality oil based on acid and peroxyde indices $\left(2.45 \pm 0.33 \mathrm{mg} \mathrm{KOH} \mathrm{g}^{-1}\right.$ and $5.47 \pm 1.05 \mathrm{mEq}$ $\left.\mathrm{kg}^{-1}\right)$. The main fruit bioactive compound was $\beta$-carotene $(832.4 \pm 0.64 \mu \mathrm{g} / 100 \mathrm{~g})$. The chromatographic profile showed a high saturated fatty acid content (53.74\%); unsaturated (46.25\%); fats were monounsaturated $(39.66 \%)$ and polyunsaturated (6.59\%). The antiatherogenic, antithrombogenic and hypocholesterolemic indices were, on average, 1.10, 2.04 and 0.84 , respectively. The spectroscopic profile exhibited bands with variation from $2918.8 \mathrm{~cm}^{-1}$ to $714 \mathrm{~cm}^{-1}$.

\section{Conclusion}

The results indicate that the consumption of isolated lipid content of the pupunha palm oil provides health protection with emphasis on the prevention of cardiovascular diseases.

Keywords: Antioxidant. Arecaceae. Fatty acids.

\section{RE S U M O}

\section{Objetivo}

A presença de fontes alimentares ricas em compostos bioativos na dieta humana torna-se fator preponderante no combate à etiologia de diversas patologias. Assim, o objetivo desta pesquisa foi avaliar o perfil de ácidos graxos, indices de funcionalidade cardiovasculares, compostos bioativos e padrão espectroscópico do óleo da pupunha vermelha e suas implicações para a saúde humana.

\section{Métodos}

O óleo foi obtido por extração via soxhlet; seu rendimento e qualidade foram determinados segundo as normas da Association of Official Analytical Chemists. Para o perfil de ácidos graxos, seguiram-se as recomendações práticas da American Oil Chemists' Society e da International Organization for Standardization. Os carotenoides e polifenóis totais foram estipulados por espectrofotometria; a constituição de grupos químicos, por espectroscopia de infravermelho. Os índices antiaterogênico, antitrombogênico e hipocolesterolêmico foram obtidos por modelos matemáticos.

\section{Resultados}

Os resultados evidenciaram um óleo com boa qualidade, com base nos índices de acidez e peróxido

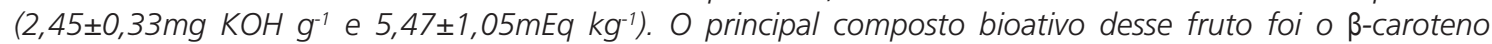
$(832,4 \pm 0,64 \mu \mathrm{g} / 100 \mathrm{~g})$. O perfil cromatográfico revelou um elevado teor de ácidos graxos saturados (53, $74 \%) ;$ os insaturados (46,25\%) se mostraram distribuídos em monoinsaturados (39,66\%) e poli-insaturados (6, 59\%). Os índices de antiaterogênico, antitrombogênico e hipocolesterolêmico foram, em média, respectivamente 1,10; 2,04 e 0,84. O perfil espectroscópico apresentou destaques com variação de $2918,8 \mathrm{~cm}^{-1}$ a $714 \mathrm{~cm}^{-1}$.

\section{Conclusão}

Os resultados indicam que o consumo do conteúdo lipídico isolado da pupunha atua na proteção da saúde, em especial para a prevenção de agravos cardiovasculares.

Palavras-chave: Antioxidante. Arecaceae. Ácidos graxos.

\section{NTRODUCTION}

Cardiovascular Diseases (CVD) have shown increasing prevalence in the world with a high degree of morbidity and mortality; genetic factors account for a high percentage of risk for their development. In Brazil, they are considered as one of the main causes of death and include as risk factors, heredity, overweight, obesity, physical inactivity, Low Density Lipoprotein (LDL), etc. 
This problem is often driven by low consumption of plant ingredients rich in bioactive compounds that protect human health. Thus, it can be inferred that one of the causes of CVD may be due to food dysregulation, taking into account that plant-based diets are associated with the prevention of cardiovascular diseases [1-3].

Thus, it is important to increase normal diet with food sources with functional basis constituents. Among these compounds, essential fatty acids such as omega ( $\omega-3, \omega-6)$ should be included, as they are directly related to the anti-atherogenic, antithrombogenic indices and reduced cholesterol rates $[3,4]$.

In addition, such sources contain fibers, minerals and bioactive compounds and their adequate amounts in the diet promote beneficial health effects, as a result of actions that prevent chronic non-degenerative and cardiovascular diseases $[4,5]$.

Functionality indices in food are based on the presence of potentially active constituents that prevent the etiology of a number of pathologies and/or act as adjuvants in the treatment processes of already existing conditions. Lipid-based components of different carbon chain sizes, with emphasis on fatty acids belonging to the omega family ( $\omega-3, \omega-6$ and $\omega-9)$, are intrinsically associated with the composition of functional indices directly linked to the reduction of the risks of atherogenic diseases, thrombogenic conditions and to the reduction in hypocholesterolemic rates $[3,4]$.

In this connection, the presence of edible Amazon oil plants fruits aims to add to the diets this range of compounds with high nutritional value and functional properties, such as those found in Amazonian fruits including, but not limited to, açaí, tucumã, bacaba, pupunha $[1,5,6]$.

In this paper pupunha (Bactris gasipaes Kunth) stands out; it is a peach palm fruit, from the Arecaceae family, originated from the tropical forests of the American continent. The weight of this fruit ranges from $0.5 \mathrm{~g}$ to $25 \mathrm{~g}$ and, when ripe, may have a red, yellow or orange epicarp and a starchy to oily mesocarp with an average of $10 \%$ to $30 \%$ oil. Such facts corroborate the importance of quantifying essential fatty acids and their functionality indexes in human health [4,5,7-9].

Given the above, considering the high lipid and bioactive compounds concentration in Bactris gasipaes Kunth, this investigation aims to evaluate the chromatographic profile and bioactive compounds present in the oil of the red peel pupunha (Bactris gasipaes Kunth), as well as their implications for human health.

\section{METHODS}

The red peel pupunha (Bactris gasipaes Kunth) samples were obtained in the Ver o Peso market located in the Metropolitan Region of the municipality of Belém, State of Pará. They were transported in plastic bags made of Low-Density Polyethylene (LDPE) and stored in the Laboratory of Food Sciences of the Universidade Federal do Pará (UFPA, Federal University of Pará), for 24 hours at a temperature of $7^{\circ} \mathrm{C}$.

Then, fruit selection procedures were carried out, separating the fruits without apparent damage from those with possible contamination caused by the presence of dirt, holes, bulging and soft parts in the fruit structure, etc. The fruits selected were soon after washed in running chlorinated and fluorinated water, sanitized with sodium hypochlorite at 200ppm for 30 minutes; then, the fruits were cooked in boiling water for 30 minutes in a stainless steel container. After cooling to room temperature, they were pulped in a stainless steel container, cut into strips and dried in an air 
circulation oven at $105^{\circ} \mathrm{C}$ (Thot 150 brand) for 18 hours. Subsequently, the sample was ground in a Willye knife mill (brand Refrinox model TE650), to obtain the flour. The oil was then extracted via solid-liquid (Soxhlet) process. After extraction, the oil obtained was placed in amber glass containers and stored at a freezing temperature of $-7^{\circ} \mathrm{C}$.

The extraction of the lipid content was performed by the solid-liquid method: the oil was obtained using a soxhlet-type device, using organic solvent (petroleum ether), complying with the standards determined by the Association of Official Analytical Chemists (AOAC) No. 948.22 [10], according to equation 1 . The evaluation of quality and conservation was determined by the Acidity Index obtained with the titrimetric method, as determined by American Oil Chemists' Society (AOCS), by method No. Cd 3d-63 [11]; and the peroxide index determined according to AOCS by the Cd 8-53 method [11].

$$
\mathrm{R}(\%)=\left(\frac{\text { Moil }}{\text { Msample }}\right) \times 100 \quad \text { Equation } 1
$$

Note: Moil: Oil mass (g); MSample: Total mass (g); R: Yield (\%).

The characterization of the fatty acids profile was performed after the preparation of the fatty acid methyl esters, following the procedures described in International Organization for Standardization 5509 [12]. After separating the phases, the supernatant was collected and analyzed by Gas Chromatography. The analyses were performed in a Gas Chromatograph (GC), Varian brand CP8410 (Autosampler), coupled to a microcomputer with the Galaxie Chomatography software, which chromatographic conditions were as follows: capillary column of fused silica SP-2560 (Supelco, USA), $100 \mathrm{~m}$ long with $0.25 \mathrm{~m}$ internal diameter, containing $0.2 \mu \mathrm{m}$ polyethylene glycol inside.

The operating conditions were: Split injection, 50:1 ratio; Column temperature: $140^{\circ} \mathrm{C}$ for 5 minutes, programmed for an elevation rate of $4^{\circ} \mathrm{C}$ per minute to $240^{\circ} \mathrm{C}$ with helium carrier gas, at 37 psi isobaric pressure, $20 \mathrm{~cm} / \mathrm{second}$ linear speed; Make-up gas: helium at $29 \mathrm{~mL} /$ minute; Injector temperature $250^{\circ} \mathrm{C}$, Varian brand CP8410 (Autosampler); Detector's temperature $250^{\circ} \mathrm{C}$. The qualitative composition was determined by comparing peak retention times with the relevant fatty acid standards. The quantitative composition was performed by area normalization, expressed as mass percentage according to the AOCS Ce 1-62 method [13].

The functionality of the lipid fractions was obtained through the Atherogenicity Index (AI) and the Thrombogenicity Index (TI), as defined by Ulbricht and Southgate [14] and the ratio Hypocholesterolemic/Hypercholesterolemic $(\mathrm{HH})$ according to Santos-Silva et al. [15]. The indices were determined according to the following mathematical models (Equations 2, 3 and 4):

$$
\begin{gathered}
\mathrm{AI}=\frac{[(\mathrm{C} 12: 0)+(4 \mathrm{XC} 14)+(\mathrm{C} 16)]}{(\Sigma \mathrm{MUFA}+\Sigma \omega-6+\Sigma \omega-3)} \\
\mathrm{TI}=\frac{(\mathrm{C} 14: 0+\mathrm{C} 16: 0+\mathrm{C} 18: 0)}{[(0,5 \mathrm{X} \Sigma \mathrm{MUFA})+(0,5 \mathrm{X} \Sigma \omega 6)+((3 \mathrm{X} \Sigma \omega 3))+(\Sigma \omega 3 /(\Sigma \omega 6))]} \\
\mathrm{HH}=\frac{(\mathrm{C} 18: 1 \omega 9+\mathrm{C} 18: 2 \omega 6+\mathrm{C} 20: 4 \omega 6+\mathrm{C} 18: 3 \omega 3+\mathrm{C} 20: 5 \omega 3+\mathrm{C} 22: 5 \omega 3+\mathrm{C} 22: 6 \omega 3)}{(\mathrm{C} 14: 0+\mathrm{C} 16: 0)} \quad \text { (Equation 3) }
\end{gathered}
$$

Note: C: represents the fatty acid chains expressed in the chromatographic profile; MUFA: Monounsaturated Fatty Acids. 
The oil samples extracted from the pupunha pulp were previously solubilized to form an 1:20 alcoholic extract with a sample diluted in 95\% ethanol with $1.5 \mathrm{~N}$ Hydrochloric Acid $(85: 15) \mathrm{v} / \mathrm{v}$. The total polyphenol content of these fractions was analyzed, according to the Folin-Ciocalteu Method [16], using a UV-Vis spectrophotometer, model UV-spectrophotometer UV-1800 (Shimadzu, Tokyo, Japan), at a wavelength of $725 \mathrm{~nm}$ and the results were calculated using the standard curve of gallic acid with the equation $\mathrm{y}=0.0017 \times(\mathrm{R} 2=0.9966)$.

The carotenoid content of pupunha oil was determined by a UVNIS spectrophotometer, Kasuaki brand, model IL-592, according to the analytical methodology for the separation and extraction of compounds with organic solvents, indicated by Rodriguez-Amaya [17], with absorbance reading. at $450 \mathrm{~nm}$ wavelength, using petroleum ether as solvent. The total carotenoid content was expressed in micrograms $(\mu \mathrm{g})$ of $\beta$-carotene [18]. The conversion of Vitamin A content was calculated as recommended by the Institute of Medicine [18] (Equation 5).

$$
\beta \text { - carotene }(\mu \mathrm{g} / \mathrm{g})=\frac{V \times A}{2592 * \times m_{0} \times 100} \times 10^{6} \quad \text { (Equation 5) }
$$

Note: *absorption coefficient in petroleum ether; A: Absorbance; m0: Sample mass (g); V: Total volume (mL).

The antioxidant capacity was determined via reduction of the ABTS radical $\left[2,2^{\prime}\right.$ - azino-bis (3-ethylbenzothiazoline-6-sulfonic acid)], according to Chen et al. [19], with the use of a UV-Vis spectrophotometer, model UV-spectrophotometer UV-1800 (Shimadzu, Tokyo, Japan), at 734nm wavelength. The antiradical capacity was calculated in triplicate, using the calibration curve $y=-0.3364 x+0.6239\left(R^{2}=0.997\right)$, with " $y$ " being the absorbance and " $x$ " the Trolox concentration expressed in $\mu \mathrm{g} / \mathrm{L}$.

The spectral bands of the sample were obtained by absorption spectroscopy in the infrared region with Fourier transformation in a spectrometer Shimadzu Corporation IR Prestige 21 Cat. n. 206-73600-36 (Kyoto, Japan), with records in the spectral frequency range of absorption 4000, to $500 \mathrm{~cm}$ 1. The sample was incorporated into Potassium Bromide $(\mathrm{KBr})$ tablets with Scan 100 and $4 \mathrm{~cm}^{-1}$ resolution. All bands were analyzed using the software Origin 8.0 program.

Statistical analyses were performed in triplicate (Mean \pm Standard Deviation) and the results obtained were analyzed statistically, with the aid of the Statistica Program version 5.0 (StatSoft, Tulsa, 2000) [20].

\section{RESULTS AND DISCUSSION}

The oil yield of the cooked peach palm fruit was on average $23.73 \% \pm 0.50$; it is thus considered an oleaginous fruit, and the yield was higher than that found in the investigation by Santos et al. [21] with the edible portion of pupunha, that yielded $17.04 \%$ lipids.

In this connection, it is important to consider that the above difference in yield may have been influenced by the variation of species, maturation, time of harvest, handling and storage of fruits. The pupunha oil quality parameters are shown in the Table 1.

The acidity and peroxide indices are considered benchmarks for the assessment of the oils and fats quality. According to the Codex Alimentarius [22], the maximum acidity and peroxide value for unrefined oils and fats according to RDC n. 270 is $4 \mathrm{mg} \mathrm{KOH} \mathrm{g}^{-1}$ and $15 \mathrm{mEq} \mathrm{kg}^{-1}$, respectively [23]. The average acidity and peroxide index found in this investigation are lower than those established by RDC n. 270 and by Food and Agriculture Organization/World Health Organization [22,23]. 
Table 1. Pupunha oil quality parameters.

\begin{tabular}{lcc}
\hline Analysis & $\mathrm{M} \pm \mathrm{SD}$ & Legislation $^{*}$ \\
\hline Acidity level $\left(\mathrm{mg} \mathrm{KOH} \mathrm{g}^{-1}\right)$ & $2.45 \pm 0.33$ & $4.00 \mathrm{mg} \mathrm{KOH} \mathrm{g}^{-1}$ \\
Peroxide content $\left(\mathrm{mEq} \mathrm{kg}^{-1}\right)$ & $5.47 \pm 1.05$ & $15.00 \mathrm{mEq} \mathrm{kg}^{-1}$ \\
\hline
\end{tabular}

Note: *Food and Agriculture Organization [23].

M: Mean; SD: Standard Deviation.

Comparing the outcome of this investigation with that of Serra et al. [24], who evaluated the quality standards of buriti (Mauritia flexuosa) oil and pracaxi (Pentachletra Macroloba) oil, high values of acidity and peroxide were found, a few above those determined in this investigation and recommended in the legislation $\left(5.76 \mathrm{mg} \mathrm{KOH} \mathrm{g}^{-1}\right.$ and $12.05 \mathrm{mEq} \mathrm{kg}^{-1} ; 5.44 \mathrm{mg} \mathrm{KOH} \mathrm{g}^{-1}$ and $8.23 \mathrm{mEq}$ $\mathrm{kg}^{-1}$, respectively). In another survey, Santos et al. [25], when assessing the Patauá (Oenocarpus bataua) oil, found averages of $1.40 \mathrm{mg} \mathrm{KOH} \mathrm{g}^{-1}$ and $9.64 \mathrm{mEq} \mathrm{kg}^{-1}$ in the acidity and peroxide index respectively, and Costa et al. [6], in their investigations with Tucumã (Astrocaryum vulgare, Mart.), found acid averages between $6.5 \mathrm{mg}$ to $20.3 \mathrm{mg} \mathrm{KOH} \mathrm{g}^{-1}$ and peroxides between 11.8 and $13.8 \mathrm{mEq}$ $\mathrm{kg}^{-1}[6]$. Most of the oils used for comparison showed higher acidity and peroxide indexes than the pupunha oils evaluated in this investigation.

These data stress the quality of this fruit and of its post-extraction by-product, emphasizing its potential in relation to other species of Amazonian oil plants. The peach palm fruit increases and diversifies the dietary sources of high-quality lipids suitable for human consumption. Another aspect of considerable relevance stems from the fatty acid composition of pupunha oil (Table 2).

Table 2, shows that the pupunha oil has a high proportional content of saturated fatty acids, in particular, the presence of palmitic acid. On the other hand, it has a low content of unsaturated acids, with a predominance of monounsaturated acids. The monounsaturated values found in this investigation were higher than those determined in other Amazonian oil plants, such as, for example, buriti (34.20\%) and Brazil nut (38.78\%) [24].

Table 2. Fatty acid profile of red peach palm oil.

\begin{tabular}{|c|c|c|c|}
\hline Peaks & Fatty acids & Number of carbons: number of double bonds & Area \% \\
\hline 1 & Myristic acid & (C14) & 0.10 \\
\hline 2 & Palmitic acid & $(C 16)$ & 50.57 \\
\hline 3 & Palmitoleic acid & $(C 16: 1 \omega-7)$ & 3.39 \\
\hline 4 & Margaric acid & (C17) & 0.11 \\
\hline 5 & Stearic acid & (C18) & 2.95 \\
\hline 6 & Oleic acid & (C18:1 w-9) & 36.27 \\
\hline 7 & Linoleic acid & $(\mathrm{C} 18: 2 \omega-6)$ & 5.18 \\
\hline 8 & Linolenic acid & $(C 18: 3 \omega-3)$ & 1.17 \\
\hline 9 & Arachdonic acid & $(C 20: 4 \omega-6)$ & 0.24 \\
\hline Fatty acids groups & & Summation fatty acids groups & \\
\hline$\sum$ Saturated Fatty acids & & $53.74 \%$ & \\
\hline$\sum$ Insaturated Fatty acids & & $46.25 \%$ & \\
\hline$\sum$ Monounsaturated & & $39.67 \%$ & \\
\hline$\sum$ Polyunsaturated & & $6.59 \%$ & \\
\hline$\sum \omega-6$ & & 5.42 & \\
\hline Total & & 100.00 & \\
\hline
\end{tabular}

Note: \%: Normalization of area expressed in percentage by mass. 
Among the rates of polyunsaturated fatty acids, the largest ones are linoleic acid $(\omega-6)$ followed by linolenic acid ( $\omega$-3). In the investigation by Santos et al. [25], with Amazonian fruits, 3 categories were listed, according to their $\omega-6$ content. The first category for values below $4.9 \%$; the second for values above 5\%; and the third one for fruits with expressive rates of around $30.0 \%$. In this connection, the result of this investigation fits the level classified as an intermediate source of omega 6. In relation to $\omega-6$ the value found in this work was higher than that found in buriti (4.5\%) [26].

The value of omega 3 determined in this investigation was higher than that found in Brazil nut $(0.155 \%)$ [24], patauá $(0.520 \%)$ [25] and castanhola nuts $(0.068 \%)$ [27]. It is noteworthy that omega 3 is directly related to the therapy of chronic non-communicable and cardiovascular diseases. This observation allows us to infer that pupunha is an important functional food $[4,26]$.

The chromatographic profile data can express red pupunha oil fractions relevance in terms of functional quality indexes. The P/S ratio in plant oils is one of the most relevant in functional terms. The lower its value, the better its action in the prevention of CVD $[1,2,5]$, which demonstrates the high functionality of the pupunha oil found in this investigation, considering its P/S ratio of 0.12 .

These data show the importance of inclusion of such fruits in the eating habits, as they are sources of omega 3, 6 and 9 . These fatty acids have a beneficial action, as antioxidant protection that acts against the etiology of different kinds of cancer, besides the anti-inflammatory activity and decreased occurrence of cardiovascular diseases. Specifically, linoleic acid has a bioactive action in cases of dermatitis and eczema, rheumatoid arthritis processes, premenstrual syndrome and stroke prevention $[4,5,25]$.

The lower the $\mathrm{Al}$ and $\mathrm{TI}$ indices, the greater the amount of anti-atherogenic fatty acids present in a given oil and/or fat, that is, the less the stimulus of this food to cause platelet aggregation [28]. The myristic, palmitic and stearic fatty acids are considered pro-thrombogenic, unlike the unsaturated ones, which are considered antithrombogenic. The data exhibited in this study, for the indexes $\mathrm{Al}$ (1.10) and $\mathrm{TI}$ (2.04), matched one of the functional qualities of this fruit, making pupunha an important food with the potential to prevent coronary diseases $[4,5]$.

The Hypocholesterolemic/Hypercholesterolemicindex (0.84) found in this investigation shows that pupunha oil is nutritionally adequate, with a greater ability to prevent serum cholesterol increase (mainly LDL) while decreasing CVD risk, with a value below $10.0[4,5]$. These results derived from the chromatographic profile confirm the functionality of this fruit in preventing cardiovascular diseases and its importance when added to the usual diet.

The quality of the chromatographic lipid profile $(\mathrm{Al}, \mathrm{TI}$, and $\mathrm{HH}$ ) revealed that pupunha oil has a high level of nutritional value and functional protection. Thus, its coadjuvant elements can act in the prevention of cardiovascular and chronic non-transmissible pathologies. In addition to this constitution, the fruit contains bioactive compounds, with their polyphenols content, antioxidant capacity and total carotenoids.

Observing the data in Table 3 in comparison with Singh's research data [29], the content of total phenolic compounds was $2.98 \mathrm{mg}$ GAE/100g and antioxidant capacity of $38.76 \mu \mathrm{mol}$ TROLOX/100g, results close to those obtained in this investigation. In contrast, Rojas-Garbanzo et al. [30], reported averages of $54 \mathrm{mg}$ to $106 \mathrm{mg}$ GAE/100g, with an average antioxidant capacity of $37 \pm 7.0 \mu \mathrm{mol}$ of Trolox Equivalents (TE)/g.

The organic action of the bioactive compounds present in pupunha, including total phenolics, carotenoids and antioxidant capacity (Table 3 ) is closely related to human growth and development 
Table 3. Bioactive compounds of pupunha fruit.

\begin{tabular}{|c|c|c|}
\hline Analysis & $\mathrm{M} \pm \mathrm{SD}$ & Vitamin A DRI ${ }^{*}$ \\
\hline Total Polyphenols (mgGAE/g) & $3.70 \pm 0.25$ & Not Determined \\
\hline \multirow[t]{4}{*}{ Antioxidant Capacity ( $\mu \mathrm{mol}$ TROLOX/100g) } & $35.35 \pm 1.05$ & Not Determined \\
\hline & & Children $1-3$ years of age: $400 \mu g \mathrm{RE}^{* *}$ \\
\hline & & Children $4-6$ years of age: $450 \mu \mathrm{g}$ RE \\
\hline & & Children $7-10$ years of age: $500 \mu \mathrm{g} R$ \\
\hline \multirow{3}{*}{$\beta$-carotene $(\mu \mathrm{g} / \mathrm{g})$} & $832.40 \pm 0.64$ & Adults: $600 \mu \mathrm{g}$ RE \\
\hline & & Pregnant women: $800 \mu \mathrm{g}$ RE \\
\hline & & Lactating: $850 \mu \mathrm{g}$ RE \\
\hline
\end{tabular}

Source: *DRI: Dietary Reference Intakes [31].

Note: ${ }^{* *} R E$ : Retinol Equivalents of $\beta$-carotene ( $\left.\mu \mathrm{g} / 100 \mathrm{~g}-\mathrm{M} \pm \mathrm{SD} 139.01 \pm 1.07\right)$.

M: Mean; SD: Standard Deviation.

and protection of the body against oxidative stress, caused by Reactive Oxygen Species (ROS) that damage cellular components such as proteins, lipids, Deoxyribonucleic Acid (DNA) and Ribonucleic Acid (RNA), through their oxidation [31,32].

In this connection, mutagenic and carcinogenic processes have their actions reduced by the consumption of food that is a source of antioxidants such as carotenoids (pro-Vitamin A), polyphenols and other compounds with antioxidant capacity that are available in sources such as pupunha.

These results expressed by the contents of total polyphenols, antioxidant capacity and beta-carotene provide evidence of the bioactive functional potential expressed in this oil. The research contents differences taken as comparative parameters are directly related to the local origin of the fruit, crop harvest, climatic conditions, extraction methods, solvents used, way of expressing the data, among others. However, regardless of these variables, this isolated lipid component revealed to be a good source of antioxidant. The combination of these properties in this lipid compound showed its potential for use in nutritional and functional compounds $[8,29]$.

The data for total carotenoids were converted into Vitamin A, according to RDC no. 269 dated 09/22/2005 [33], when considering $1 \mu \mathrm{g}$ of beta-carotene $=0.167 \mu \mathrm{g}$ of Retinol Equivalent (RE). The RE result obtained was compared to that of the Recommended Daily Intake (RDI) in Brazil [33] for individuals and groups of people from a healthy population.

Studies suggest a classification according to the amount of carotenoids, being: low (0-100 $\mu \mathrm{g} / 100 \mathrm{~g})$, moderate (100-500 $\mu \mathrm{g} / 100 \mathrm{~g})$, high (500-2000 $\mathrm{gg} / 100 \mathrm{~g})$ and very high ( $\geq 2000 \mu \mathrm{g} / 100 \mathrm{~g})$ [34]. Thus, the oil of the red peel pupunha can be considered a very high source of carotenoids (8324 $\mu \mathrm{g} / 100 \mathrm{~g})$.

According to Moreira et al. [35], a cooked fruit has $12 \mathrm{~g}$ of pulp, which corresponds to $1.62 \mathrm{~g}$ of oil and $1,348.48 \mu \mathrm{g}$ of $\beta$-carotene/g (225.19RE); therefore, considering the RDI of Vitamin $A$, of a pupunha unit this would correspond to $37.53 \%$ of the RDI for adults and approximately $45.00 \%$ for children 7 to 10 years old, which demonstrates pupunha's valuable contribution to the daily intake of pro-Vitamin A.

In research studies using the same species of pupunha, with different origins, Rojas-Garbanzo et al. [30], with peach palm fruits from Costa Rica, found an average of $1.65 \mu \mathrm{g} / \mathrm{g}$ of total carotenoids in the peach palm pulp. In turn, Hempel et al. [36] obtained a maximum content of $139.00 \mu \mathrm{g} / \mathrm{g}$ in varieties of red pupunha also from Costa Rica. In contrast, Santos et al. [37], in a study carried out with oils from palm fruits from the Amazon region, reported results of $357.4 .0 \mu \mathrm{g} / \mathrm{g}$ of carotenoids for the pupunha pulp oil, lower than that obtained in our investigation. 
The presence of high levels of carotenoids expressed in the B-carotene fraction of this fruit qualified pupunha as a source of pro-vitamin A. Its relevance in terms of vitamin consumption is based on the exogenous acquisition of these vitamins by the human body, since the body is not able to synthesize them, thus requiring the ingestion from dietary sources. The spectroscopic profile of red pupunha oil is shown in Figure 1.

The spectroscopic profile showed frequency intervals of groups of organic compounds in the oil of red pupunha, with great peaks intensity in the interval between $2918.8 \mathrm{~cm}^{-1}$ and $2858.0 \mathrm{~cm}^{-1}$. In these ranges, there are groups that evidence the quality of this oil such as alcohols, esters, ethers, carboxylic acids of great intensity, as these are compounds that are not related to the oxidative degradation processes, thus confirming the quality of this raw material $[4,5,21]$.

The presence of bands in the Frequency Range around $1752.7 \mathrm{~cm}^{-1}$ with great intensity and the peak $1165.38 \mathrm{~cm}^{-1}$ is characteristic of carbonyl groups, methyl esters, ketones and aldehydes, chemical groups frequently found in long chain fatty acids, ratifying pupunha's oil fatty acid profile pattern obtained by gas chromatography (Table 2). The same functional groups were found in the spectroscopic profiles of other Amazonian oil plants, such as sapucaia and bacaba, reported in the investigations by Pinto et al. [4] and Santos et al. [5].

The smallest spectral range of prominence presented at $714 \mathrm{~cm}^{-1}$ is related to the sequence of aliphatic chains and aromatic fatty acid rings, data that are consistent with those appearing in their chromatographic profile (Table 2). This spectral peak is similar to that presented by the spectra of the sapucaia and bacaba oils, obtained with different types of extraction, confirming the quality of the pupunha material $[4,5]$.

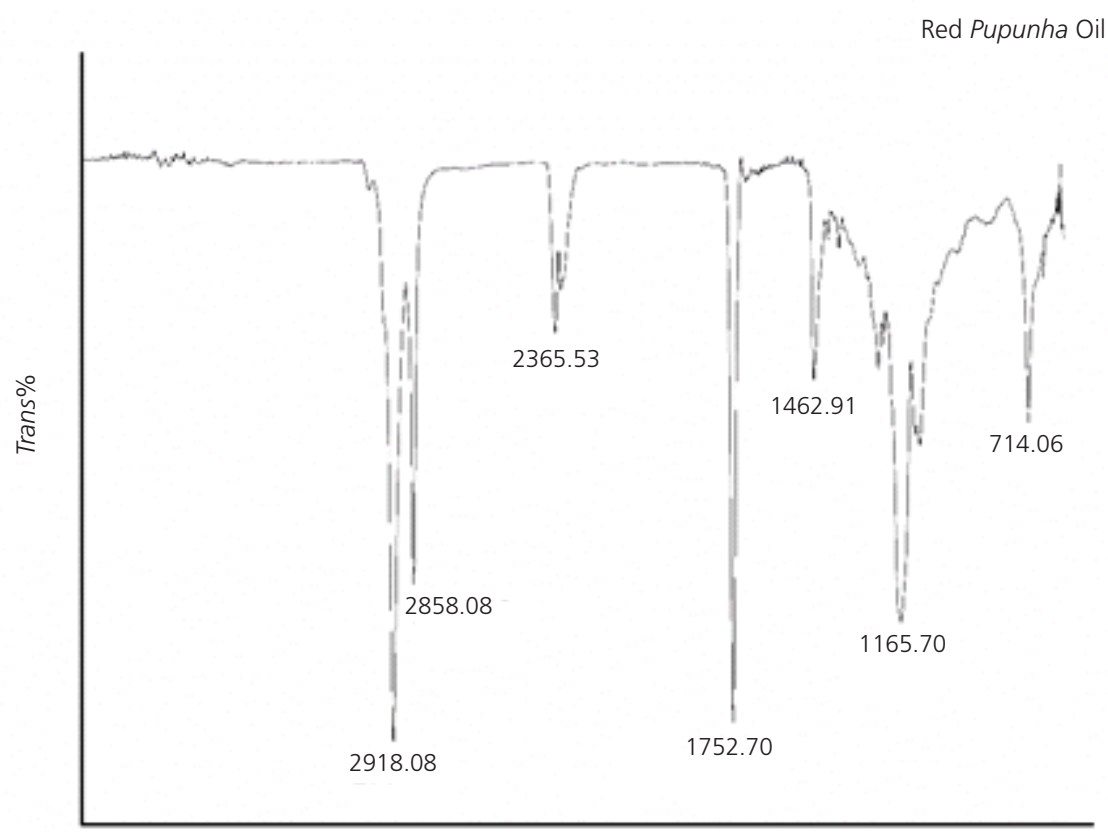

$\mathrm{cm}^{-1}$

Figure 1. Infrared spectroscopy of red Pupunha oil.

Note: cm: centimeters; \%: percentage. 


\section{CONCLUSION}

Given the data presented, the importance of including fruits of oil species such as pupunha in the human diet, as a way to obtain higher concentrations of compounds with functional-bioactive potential was evidenced.

In the lipid profile of the pupunha oil studied, the presence of $\omega-3, \omega-6$ and $\omega-9$ stands out. This result indicates a strong potential for implications in maintaining health, as it exerts a preventive action in the pathological etiologies conditions of the cardiovascular system, besides acting as an adjuvant in anti-inflammatory processes, which can reduce the occurrence of chronic non-communicable diseases.

The lipid profile reported is responsible for the low rates of atherogenicity and thrombogenicity, factors directly related to the etiology of CVD. It is also noteworthy that the high ratio Hypocholesterolemic/Hypercholesterolemic points to the prevention of LDL levels and decreased risk of CVD.

The bioactive compounds content confirms the importance of the dietary inclusion of this food source that exerts an antioxidative action against ROS - one of the factors responsible for the etiology of several types of cancer. In addition, pupunha provides bioactive action due to its carotenoids content with action in pro-Vitamin A, which helps preventing dermatological implications, rheumatoid arthritis inflammatory processes and stroke among other pathological conditions.

The carotenoid composition of this fruit makes pupunha stand out among other oil plants; in fact, it adds a significant high daily rate of pro-Vitamin A in different age groups in the Brazilian population.

\section{CONTRIBUTORS}

All authors made substantial contributions to the conception and design of this study, data gathering, and manuscript writing.

\section{RE FERE N CES}

1. Moura RS, Resende AC. Cardiovascular and metabolic effects of açaí, an Amazon plant. J Cardiovasc Pharmacol. 2016;68(1):19-26. http://dx.doi.org/10.1097/FJC.0000000000000347

2. Paz SM, Bermudez B, Cardelo MP, Lopez S, Abia R, Muriana FJG. Olive oil and postprandial hyperlipidemia: implications for atherosclerosis and metabolic syndrome. Food Funct. 2016;7:4734-44. http://dx.doi. org/10.1039/C6FO01422D

3. Fathi-Achachlouei B, Damirchi, SA, Zahedi Y, Shaddel, R. Microwave pretreatment as a promising strategy for increment of nutraceutical content and extraction yield of oil from milk thistle seed. Ind Crops Prod. 2019;128:527-33. http://dx.doi.org/10.1016/j.indcrop.2018.11.034

4. Santos OV, Carvalho RN, Costa CEF, Lannes SCS. Chemical, chromatographic-functional, thermogravimetricdifferential and spectroscopic parameters of the sapucaia oil obtained by different extraction methods. Ind Crops Prod. 2019;132:487-96. http://dx.doi.org/10.1016/j.indcrop.2019.02.043

5. Pinto RHH, Sena C, Santos OV, Costa WA, Rodrigues AMC, Carvalho Junior RN. Extraction of bacaba (Oenocarpus bacaba) oil with supercritical $\mathrm{CO}_{2}$ : global yield isotherms, fatty acid composition, functional quality, oxidative stability, spectroscopic profile and antioxidant activity. Grasas Aceites. 2018;69(2):1-8. http://dx.doi.org/10.3989/gya.0883171 
6. Costa BET, Santos OV, Corrêa NCF, França LF. Comparative study on the quality of oil extracted from two tucumã varieties using supercritical carbon dioxide. Food Sci Technol. 2016;36:322-8. http://dx.doi. org/10.1590/1678-457x.0094

7. Borges CV. Avaliações biométricas de caracteres agronômicos em progênies de pupunheira (Bactris gasipaes Kunth.) [tese]. Amazonas: Universidade Federal do Amazonas; 2016.

8. Neri-Numa IA, Sancho RAS, Pereira APA, Pastore GM. Small Brazilian wild fruits: nutrients, bioactive compounds, health-promotion properties and commercial interest. Food Res Int. 2018;103:345-36. http:// dx.doi.org/10.1016/j.foodres.2017.10.053

9. Franco TS, Potulski DC, Viana LC, Forville E, Andrade AS, Muniz GIB. Nanocellulose obtained from residues of peach palm extraction (Bactris gasipaes Kunth). Carbohydr Polym. 2019;218:8-19. http://dx.doi. org/10.1016/j.carpol.2019.04.035

10. Association of Official Analytical Chemists. Official methods of analysis. 20th ed. Maryland (DC): Association; 2016.

11. American Oil Chemists' Society. Cd 3d-63, Cd 8-53: official methods and recommended practices of the American Oil Chemists' Society. 5th ed. Illinois: Society; 1998.

12. International Organization for Standardization. 5509: animal and vegetable fats: and oils preparation of methyl esters of fatty acids. Vernier: Organization; 1978.

13. American Oil Chemists Society. Ce 1-62: official methods and recommended practices of the American Oil Chemists' Society. 7th ed. Illinois: Society; 2010.

14. Ulbricht TLV, Southgate DAT. Coronary heart disease: seven dietary factors. Lancet. 1991;338(8773):985-92. http://dx.doi.org/10.1016/0140-6736(91)91846-M

15. Santos-Silva J, Bessa RJB, Santos-Silva F. Effect of genotype, feeding system and slaughter weigt on the quality of light lambs: II fatty acid composition of meat. Livest Sci. 2002;77(2/3):187-94. http://dx.doi. org/10.1016/S0301-6226(02)00059-3

16. Ali Akbarian B, Casazza AA, Perego P. Valorization of olive oil solid waste using high pressure-high temperature reactor. Food Chem. 2011;128:704-10. http://dx.doi.org/10.1016/j.foodchem.2011.03.092

17. Rodriguez-Amaya DB. A guide to carotenoid analysis in foods. Washington (DC): International Life Sciences Institute; 2001.

18. Institute of Medicine. Food and nutrition board, standing committee on the scientific evaluation of dietary reference intakes for Vitamin A, Vitamin K, Arsenic, Boron, Cromium, Copper, lodine, Iron, Manganese, Molybdenium, Nickel, Silicon, Vanadium and Zinc. Washington (DC): National Academy Press; 2001. [cited 2018 Nov 17]. Available from: https://www.nap.edu/read/10026/chapter/1

19. Chen $Y$, Huang $B$, He, J, Han L, Zhan Y, Wang Y. In vitro and in vivo antioxidant effects of the ethanolic extract of Swertia chirayita. J Ethnopharmacol. 2011;136(2):309-15. http://dx.doi.org/10.1016/j.jep.2011.04.058

20. Statistica for Windows. Version 7.0 [software]. Tulsa: StatSoft, 2000.

21. Santos RC, Chagas EA, Filho AAM, Takahashid JA, Montero IF, Santos GF, et al. Chemical characterization of oils and fats from amazonian fruits by 1H NMR. Chem Eng Trans. 2018;64(1):235-40. http://dx.doi. org/10.3303/CET1864040

22. Agência Nacional de Vigilância Sanitária (Brasil). Resolução RDC n²70, de 22 de setembro de 2005. Dispõe sobre regulamento técnico para óleos vegetais. Brasília: Agência; 2005 [cited 2019 Jan 23]. Available from: http://bvsms.saude.gov.br/bvs/saudelegis/anvisa/2005/rdc0270_22_09_2005.html

23. Food and Agriculture Organization. Norma para los aceites de oliva y aceites de orujo de oliva. Geneva: Organization; 1985. [cited 2019 Feb 26]. Available from: http://www.fao.org/fao-who-codexalimentarius/ sh-proxy/en/?|nk=1\&url=https \%253A\%252F\%252Fworkspace.fao.org\%252Fsites\%252Fcodex\%252FSta ndards\%252FCODEX\%2BSTAN\%2B33-1981\%252FCXS_033s.pdf

24. Serra JL, Rodrigues AMC, Freitas RA, Meirelles AJA, Darnet SV, Silva LHM. Alternative sources of oils and fats from Amazonian plants: fatty acids, methyl tocols, total carotenoids and chemical composition. Food Res Int. 2018;116(1):12-19. http://dx.doi.org/10.1016/j.foodres.2018.12.028

25. Santos OV, Gonçalves BS, Macêdo CS, Conceição LRV, Costa CEF, Monteiro Júnior OV, et al. Evaluation of quality parameters and chromatographic, spectroscopic, and thermogravimetric profile of Patauá oil (Oenocarpus bataua). Food Sci Technol. Ahead of print, 2019:1-7. http://dx.doi.org/10.1590/fst.01619 
26. Forero-Doria O, Gallego J, Valdes O, Topal CP, Santos LS, Guzmán L. Relationship between oxidative stability and antioxidant activity of oil extracted from the peel of Mauritia flexuosa fruits. J Therm Anal Calorim. 2015;123(3):2173-8. http://dx.doi.org/10.1007/s10973-015-4822-7

27. Souza ALG, Ferreira MCR, Miranda LR. Silvino RCAS, Lorenzo ND, Correa NCF, Santos et al. Aproveitamento nutricional e tecnológico dos frutos da castanhola (Terminalia catappa Linn.). Rev Pan Amaz Saude. 2016;7(13):23-9. http://dx.doi.org/10.5123/S2176-62232016000300003

28. Barros PAV, Glória MBA, Lopes FCF, Gama MAS, Souza SM, Mourthé MHF, et al. Qualidade nutricional e estabilidade oxidativa de manteigas produzidas do leite de vacas alimentadas com cana-de-açúcar suplementada com óleo de girassol. Arq Bras Med Vet Zootec. 2013;65(5):1545-53. http://dx.doi. org/10.1590/S0102-09352013000500036

29. Singh TC. Avaliação dos parâmetros físico-químicos e estabilidade de compostos bioativos em óleos de polpa e amêndoa de frutos amazônicos [tese]. São Paulo: Universidade Estadual Paulista Julio de Mesquita Filho; 2015.

30. Rojas-Garbanzo C, Pérez AM, Vaillant F, Castro MLP. Physicochemical and antioxidant composition of fresh peach palm (Bactris gasipaes Kunth) fruits in Costa Rica. Braz J Food Technol. 2016;19:e2015097. http:// dx.doi.org/10.1590/1981-6723.9715

31. Giuntini EB. Alimentos funcionais. Londrina: Editora e Distribuidora Educacional; 2018.

32. World Health Organization. Political declaration of the high-level meeting of the general assembly on the prevention and control of non-communicable diseases. In: Sixty-sixth session of the United Nations general assembly, Sept 2011, New York. Resolution 66/2. New York: United Nations; 2011 [cited 2019 Jan 23]. Available from: http://www.who.int/nmh/events/un_ncd_summit2011/political_declaration_en.pdf?ua=1

33. Agência Nacional de Vigilância Sanitária (Brasil). Resolução RDC n 269, de 22 de setembro de 2005. Dispõe sobre regulamento técnico sobre a ingestão diária recomendada (IDR) de proteína, vitaminas e minerais. Brasília: Agência; 2005 [citado 2019 Jan 23]. Available from: http://portal.anvisa.gov.br/documents/33916/394219/ RDC_269_2005.pdf/2e95553c-a482-45c3-bdd1-f96162d607b3

34. Matos KAN, Lima DP, Barbosa APP, Mercadante AZ, Chisté, RC. Peels of tucumã (Astrocaryum vulgare) and peach palm (Bactris gasipaes) are by-products classified as very high carotenoid sources. Food chem. 2019;272(1):216-21. http://dx.doi.org/10.21930/rcta.vol18_num3_art:747

35. Moreira WKO, Oliveira SS, Reis JS, Paraense LRC, Guimarães AT, Silva RTL. Análise de correlação em frutos da pupunha (Bactris gasipaes Kunth). Global Sci technol. 2016;9(3):106-15.

36. Hempel J, Amrehn E, Quesada S, Esquivel P, Jiménez VM, Heller A, et al. Lipid-dissolved c-carotene, b-carotene, and lycopene in globular chromoplasts of peach palm (Bactris gasipaes Kunth) fruits. Planta. 2014;240(1):1037-50. http://dx. doi.org/10.1007/s00425-014-2121-3

37. Santos MFG, Alves RE, Roca M. Carotenoid composition in oils obtained from palm fruits from the Brazilian Amazon. Grasas Aceites. 2015;66(3)1-8. http://dx.doi.org/10.3989/gya.1062142 